\title{
Editorial
}

Nature 440, 970 (20 April 2006) | doi: 10.1038/440970a

\section{Drugs tests on trial}

http://www. nature.com/nature/journal/v440/n7087/full/440970a. html

Britain's clinical-trial regulator has no good options.

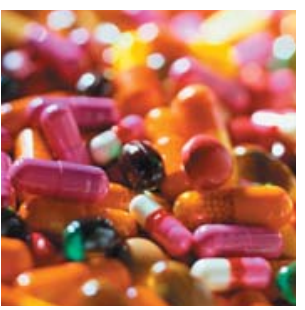

1. Following an alarming episode in London last month, in which six drug-trial participants needed emergency treatment, the UK Medicines and Healthcare Products Regulatory Agency (MHRA) says it will change the way it regulates clinical trials, at least temporarily. But this may prove more easily said than done.

2. In the trial on 13 March, six healthy subjects suffered violent reactions within minutes of ingesting an antibody drug candidate, TGN1412, which was being developed to treat autoimmune diseases such as rheumatoid arthritis. I nitial investigations suggest that the antibody itself was responsible for the side effects (see Nature 440, 855-856; 2006). On 5 April, the MHRA said it will seek advice from outside experts in determining whether drug candidates with novel modes of action should be allowed to enter clinical trials.

3. The incident at London's Northwick Park Hospital has drawn attention to the limitations of preclinical animal trials in determining the safety of drugs in humans, especially for 'humanized' antibody drugs that are targeted at mimicking human biological processes. It has also sparked some debate about whether the participants were sufficiently aware of the dangers they faced.

4. For the regulator, the immediate question is whether the existing rules strike the right balance between safeguarding trial participants and promoting the study of potentially valuable cures. Previously, the MHRA allowed initial, small-scale human safety trials to go ahead on the basis of successful animal trials and a description of how the compound works.

5. Now the agency says it will allow such trials to proceed only after review by a panel of outside experts. However, companies that have drug candidates up their sleeves don't want information on them to be shared, and any outside panel worth its salt is bound to contain people who work with rival companies. So such a provision could lead drug developers to turn their backs on Britain as a location for early-stage clinical trials.

6. The best approach is probably that practised by the US Food and Drug Administration (FDA), the only drug regulator in the world with the inhouse expertise to conduct such reviews by itself in strict confidence. The FDA, which is partly supported by fees levied on drug-makers eager to enter the lucrative US market, has 9,000 staff compared with the MHRA's 800 (although the FDA does handle food as well as drug safety).

7. One theoretical option would be a Europe-wide body set up to regulate and approve clinical trials, but the practical problems of constructing and operating such an agency would be daunting. In the interim, the MHRA may struggle to perform additional screening while satisfying confidentiality requirements.

\section{How to read?}

この文章では、事実関係が小出しになっている点に注意したい。臨 床試験事故についての説明が第 3 パラグラフまで続いているのだ。 英文記事ではよくあることだが、この記事では特にその傾向か顕著 である。これは、この記事が事実関係を主眼に置くニュースではな く、意見を述べることを目的とした論説であることに関係する。第 1 パラグラフに書かれるべき文章の論点は、事故そのものではなく、 あくまでも事態の今後の展望なのだ。また、この話題が既にかなり 多くの注目を集めていることから、読者にある程度の予備知識を期 待しているということもある。もし一度読んでむずかしいと感じた ら、同事件を扱った Nature Digest5 月号のニュース（p.18-20）や、 今月号のビジネス・ニュース (p.20-21) を読んでから、再チャレン ジしてほしい。内容に関する予備知識の有無で、英文のむずかしさ はずい分と違ってくるものだ。 


\section{Editorial}

Nature 440, 970 (20 April 2006) | doi: 10.1038/440970a

\section{試される医薬品臨床試験}

http://www. nature.com/nature/journal/v440/n7083/full/440429a.html

英国の臨床試験の規制当局には打つべきよい手がない。

1. 先月、 6 人の臨床試験（治験）参加者が 救急治療を受けるに至ったロンドンでの 憂慮すべき出来事を受けて、英国医薬品 医療製品規制庁 (MHRA) は、臨床試験 の規制方法を少なくとも暫定的に変更す ると発表した。しかしこれは、いうのは やさしくても、実行するのはむずかしい かもしれない。

2. 3 月13日に行われた臨床試験で、6 人の健康な被験者が抗体医薬品候補 TGN1412 を服用して数分後に激しい副 作用に襲われた。TGN1412は、関節 リウマチのような自己免疫疾患の開発中 の治療薬だった。当初の調査では、この 抗体自体が副作用の原因であることが示 唆されている (Nature 440, 855-856; 2006 参照)。4月 5 日、MHRA は、新 しい作用様式をもつ医薬品候補について 臨床試験の実施を決定する際には、外部 の専門家の助言を求めることを発表した。

3. ロンドンのノースウィックパーク病院で 起きた今回の事故は、特に人間の生物学 的過程を模倣することを目標とした「ヒ 卜化」抗体医薬品の場合、前臨床動物実 験で人間にとっての薬物の安全性を調べ ることに限界があるという点で注目を集 めた。また、臨床試験参加者が試験の危 険性を十分に認識していたかどうかをめ ぐっての論争も起こった。

4. 規制当局にとっては、現行の規則で臨床 試験参加者の安全確保と有望な治療薬候 補の研究促進の適正なバランスがとれる かどうかが当面の問題となる。MHRA は これまでに、動物実験の成功と薬剤化合 物の作用過程の説明を受けて、初期段階 の小規模なヒ卜安全性試験の実施を許可 したことがある。

5.このような試験の実施は、外部の専門家 パネルによる審査を経てから許可するこ とにする、とMHRAは発表している。
しかし薬剤候補をひそかに用意している 企業にとっては、その情報の公開は望ま しいことではなく、まともな外部専門家 パネルにライバル会社の関係者が含まれ るのは必至だ。そのため、このような規 定によって、製薬会社が英国での初期臨 床試験の実施に見切りをつけることにな りかねない。

6. おそらく最善の方法は、米国食品医薬品 局（FDA）が実践しているものだろう。 FDA は、このような審査を内部の専門ス タッフによって秘密裏に実施できる世界 で唯一の医薬品規制当局である。その運 営資金の一部は、もうけの多い米国市場 への参入に熱心な製薬会社から徵収され た手数料で賄われている。FDA は 9,000 人のスタッフを擁しているが、これに対 して MHRA のスタッフは 800 人に過ぎ ない（ただし FDA は、医薬品のほかに食 品の安全性も担当している)。

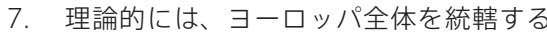
組織を設立して、臨床試験の規制と承認 を行うという案もあるが、これにはその ような機関の創設、運営という非常にむ ずかしい実際問題をともなう。当面の間 MHRA は、機密保持という必要条件を守 りつつ審査を強化するのに苦労すること になるだろう。

\section{Words and phrases}

1. more easily said than done : 「いうはやす し、行うはかたし」ということわざ「(it/that is) easier said than done」のバリエーション。

2. ingest: 「経口摂取する」こと。ここは医薬品 なので、「服用」の意味。

3. spark debate : spark には、「〜の引き金に なる」「〜を引き起こす」という意味があり、「論 争を巻き起こす」という意味になる。

4. strike the right balance between $A$ and B : 「A と B の正しいバランスをとる」とい う意味の慣用句。この「strike」という動詞には、 「(姿勢や態度を) とる」という意味がある。

5. have ... up their sleeves : 「奥の手や妙案 などをひそかに用意しておく」という意味。「up one's sleeves」とは袖の上のほうのことで、 そこに何かを隠しもっているというのがもと もとの意味。トランプゲームでのとっておき のカードや、手品の種をしまっておいたこと が語源とされる。

5. worth one's salt: 「給与に見合う働きがあ る、有能である」という意味の成句。ラテン 語の「塩」が給料を意味したことに由来する。

5. provision: 法律、規則や契約上の「規定」の ことで、ここでは MHRA による臨床試験規制 の根拠となる規定を指す。

5. turn one's backs on: 文字通りの「〜に背 を向ける」という意味から、転じて「無視する。 「見捨てる」といった意味で使われる。

6. in confidence:「内緒で」「秘密で」という 意味。この場合の「confidence」は、「秘密」 の意味である。

6. levy on ... : 税金、罰金、手数料などを「(人 や組織）に課す」「…から徵収する」こと。

6. lucrative :「もうかる」「収益性の高い」こと を意味する。

7. daunting:「ひるませる」「気力をくじく」と いう意味の「daunt」の形容詞形。仕事など が「非常に困難で、気力をくじく」こと。

7. in the interim :「その間」「それまでは」とい う意味の慣用句。「interim」は「合間」「しばら くの間」を意味する。「in the meantime」「in the meanwhile」「meanwhile」と同義。

\section{Science key words}

2. autoimmune diseases: 自己免疫疾患 本来、外来物質のみに対して働くべき免疫系が 自己の体の正常な細胞や組織に反応し、自己組 織を破壊する病気の総称。関節リウマチ、1 型 糖尿病などが含まれる。

2. rheumatoid arthritis: 関節リウマチ 関節に炎症を生じる自己免疫疾患。関節が破壊 されるにともない、関節痛や関節の変性・変形
を生じる。鎮痛剤・免疫抑制剤を使った対症療 法のみで、根本的な治療法はまだない。 antibody: 抗体 生体內に進入した非自己物質（抗原）が免疫系に 認識されることにより産生·分泌される、免疫グロ ブリンとよばれるタンパク質。抗原と特異的に結合 し、抗原を生体内から除去するように㗢く。 modes of action: 作用様式（機序） 薬剂などが投与されてから、その成分が細胞·組織 などに到達·作用し、目的の効果を生むまでのしくみ。 